University of South Carolina

Scholar Commons

\title{
The Effects of Discipline Membership and Experience in the Field on Scholars' Book and Journal Format Preferences
}

Ana Dubnjakovic

University of South Carolina - Columbia, ANA@mailbox.sc.edu

Follow this and additional works at: https://scholarcommons.sc.edu/lib_facpub

Part of the Collection Development and Management Commons

\section{Publication Info}

Postprint version. Published in Collection Management, 2019.

(c) 2019 The Author(s). This is an Accepted Manuscript of an article published by Taylor \& Francis in Collection Management on September 30, 2019, available online: https://www.tandfonline.com/doi/full/ $10.1080 / 01462679.2019 .1669251$.

Dubnjakovic, A. (2019). The Effects of Discipline Membership and Experience in the Field on Scholars' Book and Journal Format Preferences. Collection Management, 1-17. https://doi.org/10.1080/ 01462679.2019 .1669251

This Article is brought to you by the University Libraries at Scholar Commons. It has been accepted for inclusion in Faculty and Staff Publications by an authorized administrator of Scholar Commons. For more information, please contact digres@mailbox.sc.edu. 
The Effects of Discipline Membership and Experience in the Field on Scholars' Book and Journal Format Preferences

\section{INTRODUCTION}

Current publishing landscape consists of a perplexing maze of formats leased and sold to libraries in a variety of byzantine ways. Libraries are rising to the challenge and using ever more sophisticated integrated library systems (ILS) to track purchases, organize and catalog materials and track usage. With ever increasing portions of the materials budget allocated to continuing resources (Murata and Pan, 2018), most of which are only available in digital formats, librarians struggle to meet user demand and grapple with associated challenges resulting in need for format usage studies. Understanding how scholars in various disciplines and at different stages of their career see continuing resources and monographs in electronic and print formats is central to helping academic librarians maintain collections reflective of patrons' need. The current study focuses on examining material preferences taking into account just such disciplinary differences and experience levels among scholars. Additionally, humanists in the first few years of their career might differ in their preferences from their more experienced colleagues, and this might be true of scholars in other disciplines as well. Examination of interaction effects between disciplines and experience provides answers to those questions.

\section{LITERATURE REVIEW}

\section{E-book format preferences}

One of the most recent e-book format preference studies focused on whether the subject discipline preference would vary depending on the publisher (Weijing, Van Ballegooie, \& Robertson, 2018). Authors found that this is, indeed, the case and that while disciplines play a part in format preferences within publisher collections (i.e., history books across publisher platforms had a much higher print usage than their online counterparts), overall preferences varied considerably depending on the publisher. For instance, Oxford University Press books were predominantly preferred in print in 18 out of 20 subjects. Cambridge University Press and Duke University Press had more mixed results with 11 subjects privileging online access, six subjects print and three tied for Cambridge UP, and 14 subjects with print books preference, four subjects with online preference and two tied for Duke UP.

Rather than focusing on subject discipline, another recent study focusing on student population examines e-book preferences through the lens of Technology Acceptance Model (TAM) (Smith et al., 
2019). Authors conclude previous experience and comfort with e-book as a technology plays an important role in e-book adoption. Lewellen, Bischof, \& Plum, (2016) examined a number of factors influencing e-book preferences in Proquest's Electronic Book Library including subject membership, however this proved problematic given the unequal distribution of available material across disciplines. Looking at studies focusing on individual subjects Ritchie \& Skoglund (2015) found health researchers increasingly favored e-books. However, given the relatively high circulation statistics for print books, and the high cost of e-book downloads, authors conclude e-books might not be a fiscally prudent investment.

\section{E-book usage and adoption}

Current E-books usage studies predominantly focus on informative cross-publisher comparisons of academic e-book platforms (e.g., Yuan, Van Ballegooie \& Robertson, 2018; Tucker, J., 2016).

Predominantly conducted at single institutions, these studies nevertheless provide a valuable picture of specific publisher supplied features and their influence on usage as compared to print books. While most focus on broad issues and concerns, some raise potentially serious specific concerns such as accessibility issues which affect users with reading disabilities who rely on screen reading technologies (Mune \& Agee, 2016).

Most e-book studies involving discussion of disciplinary membership focus on single disciplines and provide insights into format preferences among, for example, geology faculty and students (Foote \& Rupp-Serrano, 2010), business students (Simon, 2011), and humanities scholars (Horava, 2008). Even though most are conducted at single institutions, these studies are invaluable in providing in depth descriptions of information behavior within a single discipline as well as building a potential foundation for future cross-comparisons between multiple disciplines. For instance, although e-books seemed to be less popular than print in all of the above studies and users only read small portions of e-books, rates of adoption seem to be lower in humanities.

Few studies compare scholars across multiple disciplines. In their recent study of e-book information behavior from discovery to reading patterns, Zhang \& Promann (2017) include 12 participants from academic backgrounds as diverse as theatre and electrical engineering. They also take into account participants' education level (i.e., masters student, associate professor) and level of experience with e-books (i.e., beginner to advanced). Given the scope of the study, the small sample is expected, however, the disciplinary categories were only used to describe participants and no explicit 
cross-comparisons were attempted. Additional research in this area approaches subject disciplines through the lens of e-book subjects rather than users' disciplinary membership. Levine-Clark \& Paulson (2015) use broad collection disciplinary categories to compare e-book usage across platforms. Similarly, Carrico et al. (2015) use vendor supplied data to assess disciplinary differences in e-book usage patterns at their institution for over 15,000 e-books. Their findings indicate broad disciplinary usage differences between STEM and medicine disciplines and humanities and social sciences. However, these usage differences were founded on call number based e-book subjects. Given the increasingly interdisciplinary nature of scholarly literature, it would be challenging to ascribe those differences to discipline based differences inherent in scholars' information behavior or attitudes. In similar vein, Knowlton (2016) describes disciplinary differences in print and e-book usage at his institution providing a useful model for possible implementation at other institutions to aid in collection management decisions.

Limited research also attempts to link e-book availability and usage. Scott and Best (2016), examined Choice reviewed titles and found over $77 \%$ were available in e format. Although scholars across disciplines preferred print, usage reflected disciplinary preference for books in general. For instance, behavioral and social scientists checked out greater numbers of both print and e-books than humanities or natural scientists. However, the book sample was relatively small, and the authors identified additional issues such as relevancy of the collection to users, rates at which e-titles were accumulated, and quality of bibliographic records.

As of the time of writing no studies include experience in the discipline regarding e-book adoption and usage as an interaction variable between experience and disciplinary membership.

\section{E-journal preferences}

Previous journal format preference studies predominantly indicate support for electronic format across disciplines and age groups although science scholars seem to lead the trend. A recent study contrasts humanities and social science and engineering scholars in terms of their journal preference. Their findings indicated that the engineering scholars believed e-journals had more useful features than print journals by a much larger margin than their colleagues in humanities and social sciences (Martins, Machado, Fernandes \& Ribeiro, 2015). Additionally, Bar-lllan et al. found scholars in sciences preferred journals in electronic format as early as 2005 (Bar-Ilan \& Fink, 2005). This detailed study also includes an excellent summary of reasons for such preference, with ease of access, enhanced search capabilities, 
ability to share online, and increased availability of recent articles listed as top reasons for this preference. Mathematicians also preferred e-journals by a large margin citing features such as: browsability, availability of back issues, as important characteristics of e-journals (Salisbury, 2005). Furthermore, faculty in agriculture and biological science at the University of Arkansas overwhelmingly opted for electronic format when asked which they would keep if only one format was offered (Salisbury, 2004).

Reasons for format preferences cited by humanities scholars varied greatly. Some of the disciplines within humanities proved to be an exception due to the unique research demands. For instance, artists remain primarily concerned with the quality of the illustrations, and so their preferences are contingent on the quality of the digital reproduction (Robinson, 2010). This is hardly surprising as previous research shows digitized illustrations in art journals continues to be a poor substitution for print (McCann \& Ravas, 2010). For historians, e- journals remained problematic because of the lack of retrospective content vital to their research, and, perhaps more importantly, because of their reliance on primary source materials and monographs (Talja \& Maula, 2003). English literature scholars saw the potential of e-journals as a "tool to assist in conducting research, a way of scanning a lot of material quickly" early on (Ellis \& Oldman, 2005). However, they also expressed a strong preference for print once relevant research material was discovered using the convenience of electronic format.

\section{E-journal usage and adoption}

Studies of e-journals, which currently represent a much higher proportion of academic libraries collections than e-books, describe platform and publisher differences crucial in making the content accessible to users (e.g., Dermody \& Majekodunmi, 2011). Others provide insights into user information behavior (e.g., CILIP, 2011; Nicholas, Williams, Rowlands, \& Jamali, 2010; Rowlands, Nicholas \& Jubb, 2009; Whitmire, 2002).

Nicholas, Williams, Rowlands, \& Jamali (2010) provide a detailed picture of e-journal usage across various science disciplines and history using a sample from multiple UK institutions. The only variable considered in the interdisciplinary context was Problems accessing electronic full text. However, the variable concerned frequency with which those problems were present in the literature rather than eliciting opinions and attitudes from scholars. Whitmire (2002) used Biglan's typology of academic disciplines to study undergraduate students' information seeking behavior focusing on use of electronic 
indexes to access journal articles. Her findings indicate differences among pure and applied as well as life and non-life disciplines as defined by Biglan (1973). Talja and Maula (2003) studied scholars in nursing science, literature/cultural studies, history and ecological environmental science finding that ejournals tend to receive heavier use where directed searching was preferred than those where browsing and citation chaining, popular among humanities scholars, were the norm.

Experience in the field was briefly addressed by Speier \& Palmer (1999) who used age as a proxy. Because e-journals were relatively new and unfamiliar to academics at the time their study was conducted, their research mostly focused on perceived legitimacy of e-journals as compared with print among business faculty. Their results indicate younger business faculty were more aware of e-journals while their more experienced and/or tenured colleagues were more likely to publish in them.

Additionally, those publishing in e-journals tended to be less concerned with tenure and promotion. These results reflect the darker side of academic publishing where tenure considerations tend to be one of the main drivers in decisions regarding publishing and engagement with the literature.

\section{METHODOLOGY}

The current study used seven variables (data and documentation) from the Ithaka S+R US Faculty Survey 2015 (Wolff, Schonfeld \& Rod, 2016) downloaded from the ICPSR website ${ }^{1}$ (which also hosts other Ithaka data sets in the series from 2006, 2009 and 2012). Chosen variables, included in the appendix, consist of 7 questions related to attitudes and opinions about library collections and services in regards to electronic and print formats.

Ithaka researchers reached out to 145,550 university faculty receiving a total of 9,203 responses for a response rate of $6.3 \%$. Participants included 1,498 (16.3\%) faculty with up to 10 years of experience, 2,742 (29.8\%) with 11 to 20 years of experience, and 4,799 (52.1\%) with more than 21 years of experience in their fields. Another 164 (1.8\%) failed to answer the question and were excluded from the study. The participants were classified as social scientists 3,764 (40.9\%), natural scientists 2,296 (24.9\%), humanities scholars 2,619 (28.4\%), medical researchers 388 (4.2\%), and area studies 138 (1.5\%).

\footnotetext{
${ }^{1}$ Wolff, Christine, Rod, Alisa B., and Schonfeld, Roger C. Ithaka S+R US Faculty Survey 2015. Ann Arbor, MI: Interuniversity Consortium for Political and Social Research [distributor], 2016-11-04.

https://doi.org/10.3886/ICPSR36586.v1
} 
All analytical procedures were conducted using IBM SPSS version 25 software. A $3 \times 5$ factorial ANOVA procedure was used in the study to assess differences in faculty attitudes toward print and electronic resources based on broad disciplinary membership and experience in their respective fields. In addition to standard metrics, results include partial eta squared values which indicate the relative magnitude of the effect size. Values between 0.01 and 0.06 are associated with small effect, values between 0.07 and 0.14 a medium effect and values above 0.15 large effect (Warner, 2012). Only significant general mean interactions were reported using general linear model procedure (Becker and Coolidge, 1991). Bonferroni post hoc tests were used to distinguish between subgroupings.

\section{RESULTS}

As seen in Table 1, skew and kurtosis levels were within acceptable ranges and the normality assumption held for all variables included in the study. Full questions and responses which were edited for brevity in this section are included in the appendix. All variables apart from grouping factors were rated on a 1 to 10 scale, where 1 indicated "the statement described me not at all well" and 10 "the statement described me extremely well." Disciplines included: area studies, humanities, natural sciences, social sciences and medicine. In the original instrument, experience in the field was measured in 5 year increments and the respondents were divided in 5 groups (from 0 to 5, 6-10, 11-15, 16-20, and over 21). The variable was recoded into 3 groups in 10 year increments (i.e., 0 to 10, 11-20 and over 21) for the present study. Overall, means indicate a great variety of opinions with the lowest on $E$-books prevalent in 5 years $(\mathrm{M}=3.94)$ and the highest on Only E-journals in libraries $(\mathrm{M}=7.85)$.

Insert Table 1. Descriptive statistics for all variables

\begin{tabular}{llllllll}
\hline Variable & N & M & SD & Min. & Max. & Skew & Kurtosis \\
\hline Print monograph relevance & 9117 & 6.51 & 3.035 & 1 & 10 & -.488 & -1.082 \\
E-books prevalent in 5 years & 9122 & 3.94 & 2.902 & 1 & 10 & .587 & -.971 \\
Replace print with e collections & 9121 & 6.14 & 3.270 & 1 & 10 & -.357 & -1.331 \\
Only e journals in libraries & 9119 & 7.85 & 2.649 & 1 & 10 & -1.272 & .545 \\
Only e format publishing & 9127 & 6.90 & 3.073 & 1 & 10 & -.699 & -.867 \\
Discipline & 9203 & 1.00 & 0.999 & 0 & 4 & .606 & -.413 \\
Experience & 9039 & 2.37 & 0.751 & 1 & 5 & -.711 & -.897 \\
\hline
\end{tabular}


Correlations presented in Table 2 include all variables excluding the factors (i.e., discipline and experience). All correlations were significant at $p<0.001$ level. The highest correlations were recorded between Only e-format publishing and Only e-journals in libraries ( $r=0.699)$, and Only e-format publishing and Replace print with e collections ( $\mathrm{r}=0.681$ ). Most notably, Print monograph relevance variable negatively correlated with all other variables included in the study indicating that the more participants valued print monographs, the less they were likely to think e-books would be prevalent in 5 years $(r=-0.301, p<0.001)$, print collections in libraries should be replaced with e-collections $(r=-0.366$, $p<0.001)$, libraries should collect only e-journals $(r=-0.342 p<0.001)$ or that they would be comfortable publishing in e-journals only $(r=-0.371 \mathrm{p}<0.001)$.

Table 2. Correlations

\begin{tabular}{llcllc}
\hline Construct & $\mathbf{1}$ & $\mathbf{2}$ & $\mathbf{3}$ & $\mathbf{4}$ & $\mathbf{5}$ \\
\hline 1. Print monograph relevance & 1.000 & & & & \\
2. E-books prevalent in 5 years & $-.301^{* *}$ & 1.000 & & & \\
3. Replace print with e collections & $-.366^{* *}$ & $.434^{* *}$ & 1.000 & & \\
4. Only e journals in libraries & $-.342^{* *}$ & $.347^{* *}$ & $.645^{* *}$ & 1.000 & \\
5. Only e format publishing & $-.371^{* *}$ & $.398^{* *}$ & $.681^{* *}$ & $.699^{* *}$ & 1.000 \\
\hline
\end{tabular}

Factorial $3 \times 5$ ANOVA results are presented in Table 3. Although the effect size was small, for Print monograph relevance main effect of experience $\left(F(2,8959)=4.672, p<0.001\right.$ partial $\eta^{2}=0.001$ (Figure 1)) was statistically significant indicating there is a difference between faculty in their first 10 years in the field $(M=6.31), 11$ to 20 years in the field $(M=6.43)$ and those with over 21 years in the field $(M=6.76)$. Similarly, the effect of discipline $\left(F(4,8959)=258.875, p<0.001\right.$, partial $\eta^{2}=0.104$ (Figure 2)) was statistically significant indicating there is a difference between social scientists $(M=6.09)$, natural scientists $(M=5.32)$, humanists $(M=8.02)$, medicine faculty $(M=5.14)$ and area studies faculty $(M=7.94)$. The interaction between discipline and experience in the field $F(8,8959)=5.630, p<0.001$, partial $\eta^{2}=$ 0.005 (Figure 3) was significant as well indicating opinions about print monograph relevance are going to be different for humanists at the beginning of their career and for those with over 21 years of experience. Similarly, social scientists and scholars in all other disciplines are going to be similarly affected by experience when it come to their views on print monograph relevance.

At least three trends are readily observable. Currently, humanists appear to be only slightly affected by experience $\left(M_{10}=8.11, M_{11}=8.02, M_{21}=7.94\right)$, while area studies faculty $\left(M_{10}=7.07, M_{11}=8.29\right.$, 
$\left.M_{21}=8.43\right)$ and social scientists $\left(M_{10}=5.74, M_{11}=6.02, M_{21}=6.52\right)$ appear to have more favorable attitudes to print monographs as they gain more experience in their respective fields. Finally, medicine faculty $\left(M_{10}=5.20, M_{11}=4.97, M_{21}=5.25\right)$ and natural scientists $\left(M_{10}=5.43, M_{11}=4.87, M_{21}=5.66\right)$ seem to have the least favorable print monograph view overall, which is more pronounced among the 11 to 20 years of experience group.

Table 3. ANOVA results by level of experience and discipline

\begin{tabular}{|c|c|c|c|c|c|c|c|c|c|}
\hline \multirow{4}{*}{ Construct } & \multicolumn{9}{|c|}{ Factor } \\
\hline & \multicolumn{3}{|c|}{ Experience } & \multicolumn{3}{|c|}{ Discipline } & \multicolumn{3}{|c|}{ Interaction } \\
\hline & \multirow[b]{2}{*}{$\mathbf{F}$} & \multirow[b]{2}{*}{$\mathbf{p}$} & \multicolumn{2}{|l|}{ Partial } & \multirow[b]{2}{*}{$\mathbf{p}$} & \multicolumn{2}{|c|}{ Partial } & \multirow[b]{2}{*}{$p$} & \multirow{2}{*}{$\begin{array}{l}\text { Partia } \\
\eta^{2}\end{array}$} \\
\hline & & & $\eta^{2}$ & $\mathbf{F}$ & & $\eta^{2}$ & $\mathbf{F}$ & & \\
\hline Print monograph relevance & 4.672 & 0.009 & 0.001 & 258.875 & 0.000 & 0.104 & 5.630 & 0.000 & 0.005 \\
\hline E-books prevalent in 5 years & 0.188 & 0.289 & 0.000 & 134.571 & 0.000 & 0.057 & 1.460 & 0.166 & 0.001 \\
\hline Replace print with e collections & 14.569 & 0.000 & 0.003 & 84.138 & 0.000 & 0.036 & 0.931 & 0.489 & 0.001 \\
\hline Only e journals in libraries & 9.367 & 0.000 & 0.002 & 99.410 & 0.000 & 0.042 & 1.338 & 0.219 & 0.001 \\
\hline Only e format publishing & 10.561 & 0.000 & 0.002 & 103.200 & 0.000 & 0.044 & 0.733 & 0.662 & 0.001 \\
\hline
\end{tabular}

Figure 1

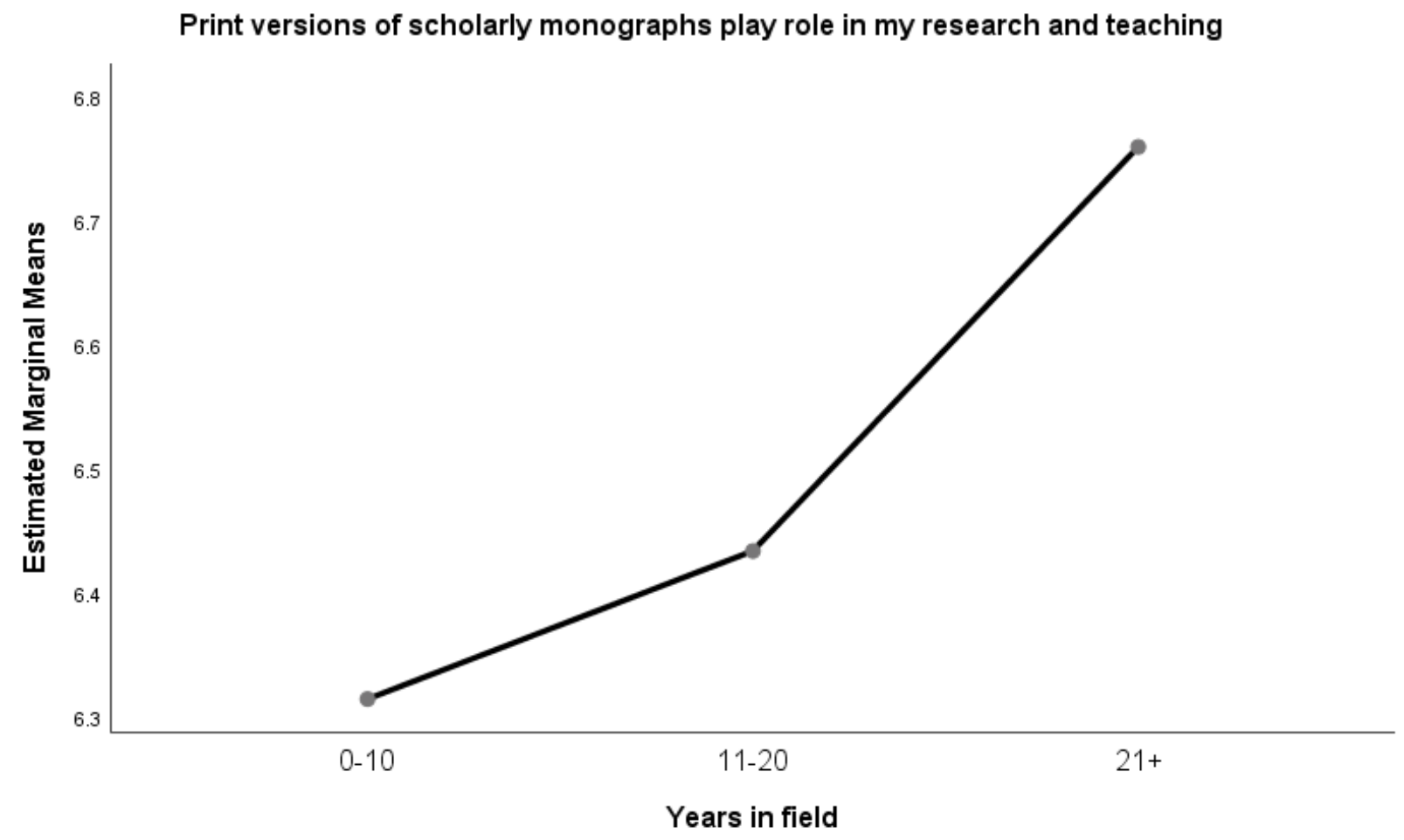


Figure 2

Print versions of scholarly monographs play role in my research and teaching

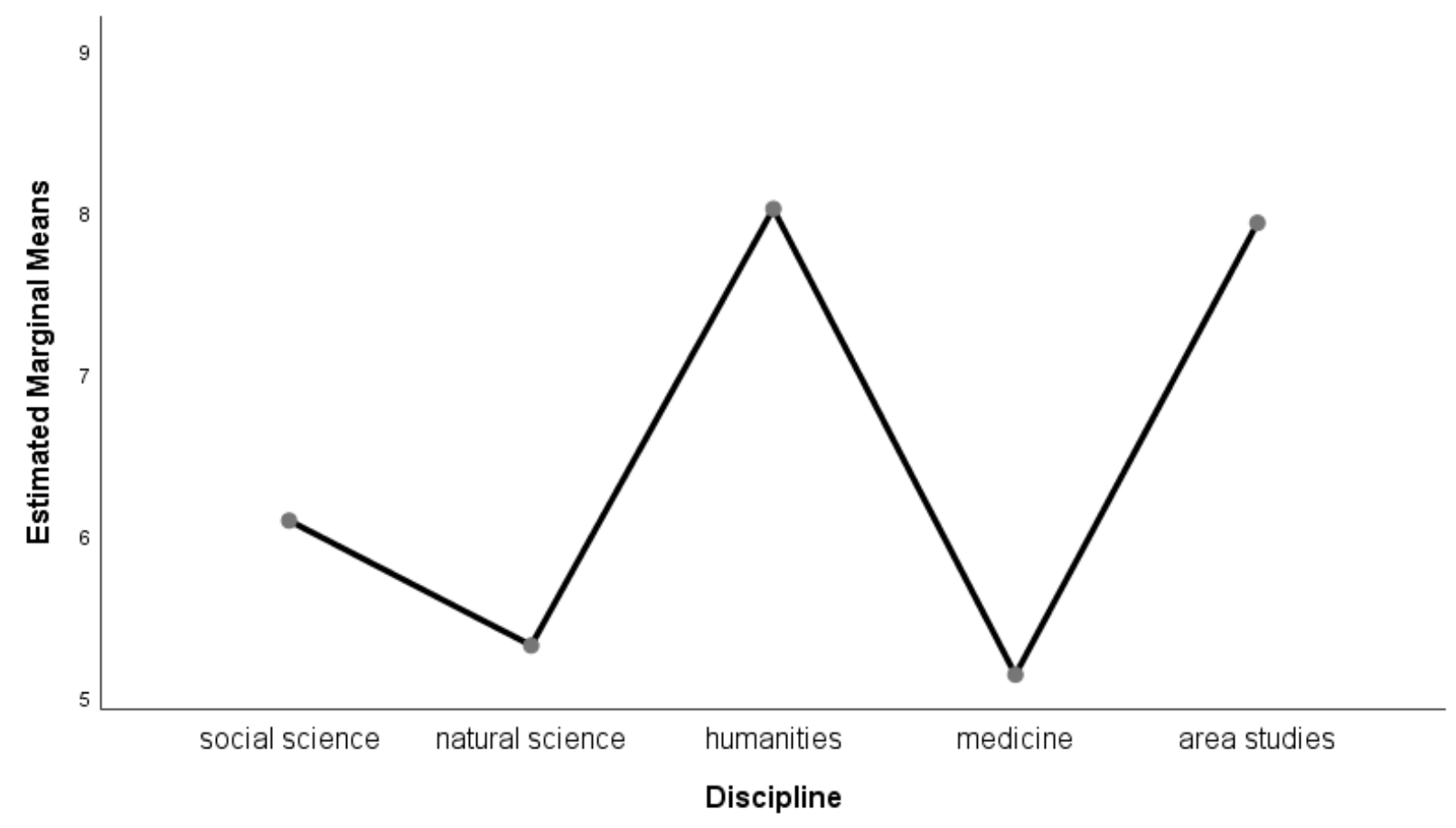

Figure 3 
Print versions of scholarly monographs play role in my research and teaching

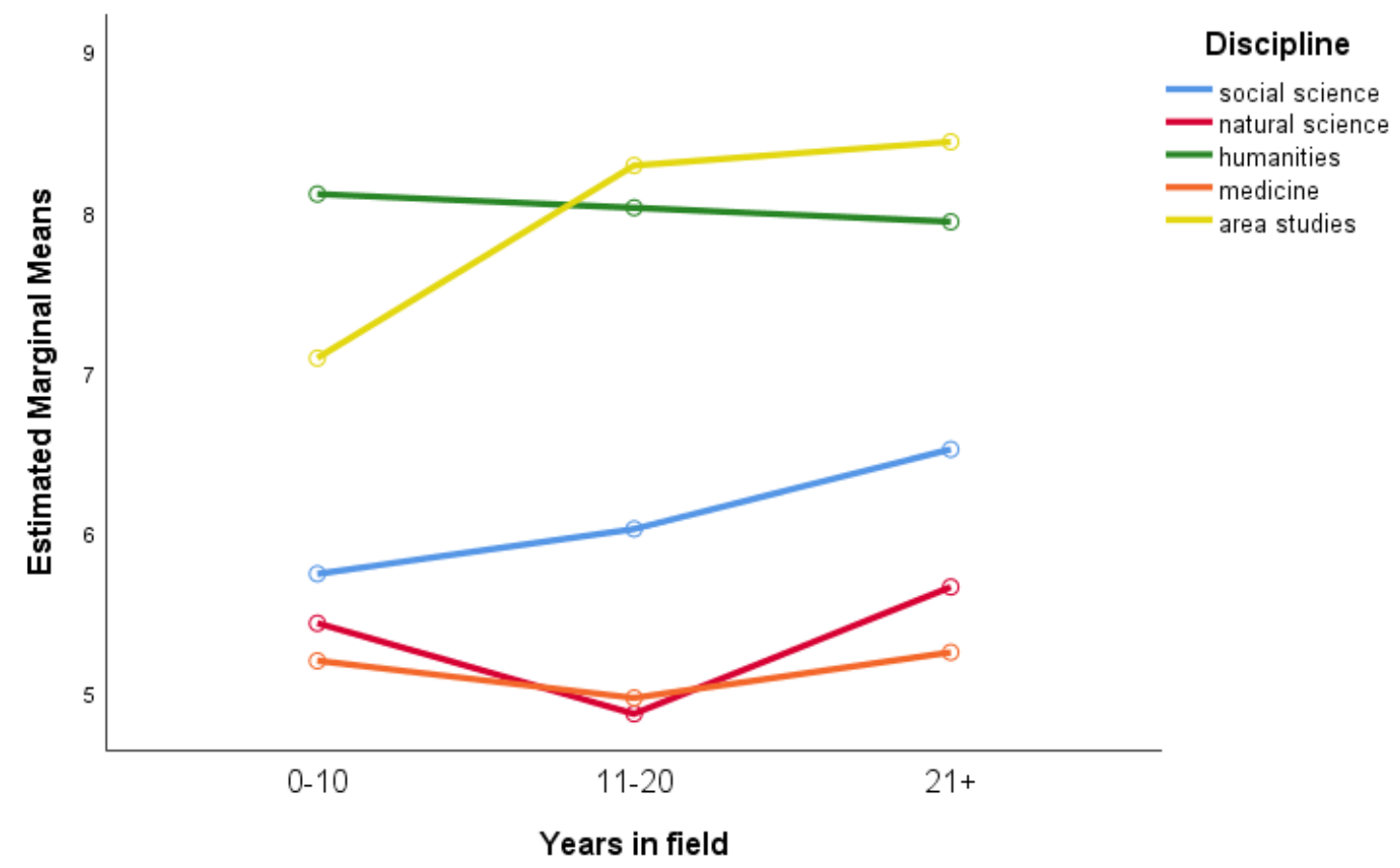

For E-books prevalent in 5 years only the main effect of discipline $(F(2,8965)=134.571, p<$ 0.001 , partial $\eta^{2}=0.057$ (Figure 4)) was statistically significant indicating there is a difference between social scientists $(M=4.15)$, natural scientists $(M=4.64)$, humanists $(M=2.76)$, medicine faculty $(M=5.74)$ and area studies faculty ( $M=3.06)$. Overall, medicine is the only discipline group slightly above the mean, while all others seem to hold less optimistic attitudes toward e-book dominance, with humanities and area studies at the lowest end of the spectrum.

Figure 4 
Within the next five years, the use of e-books will be prevalent among faculty

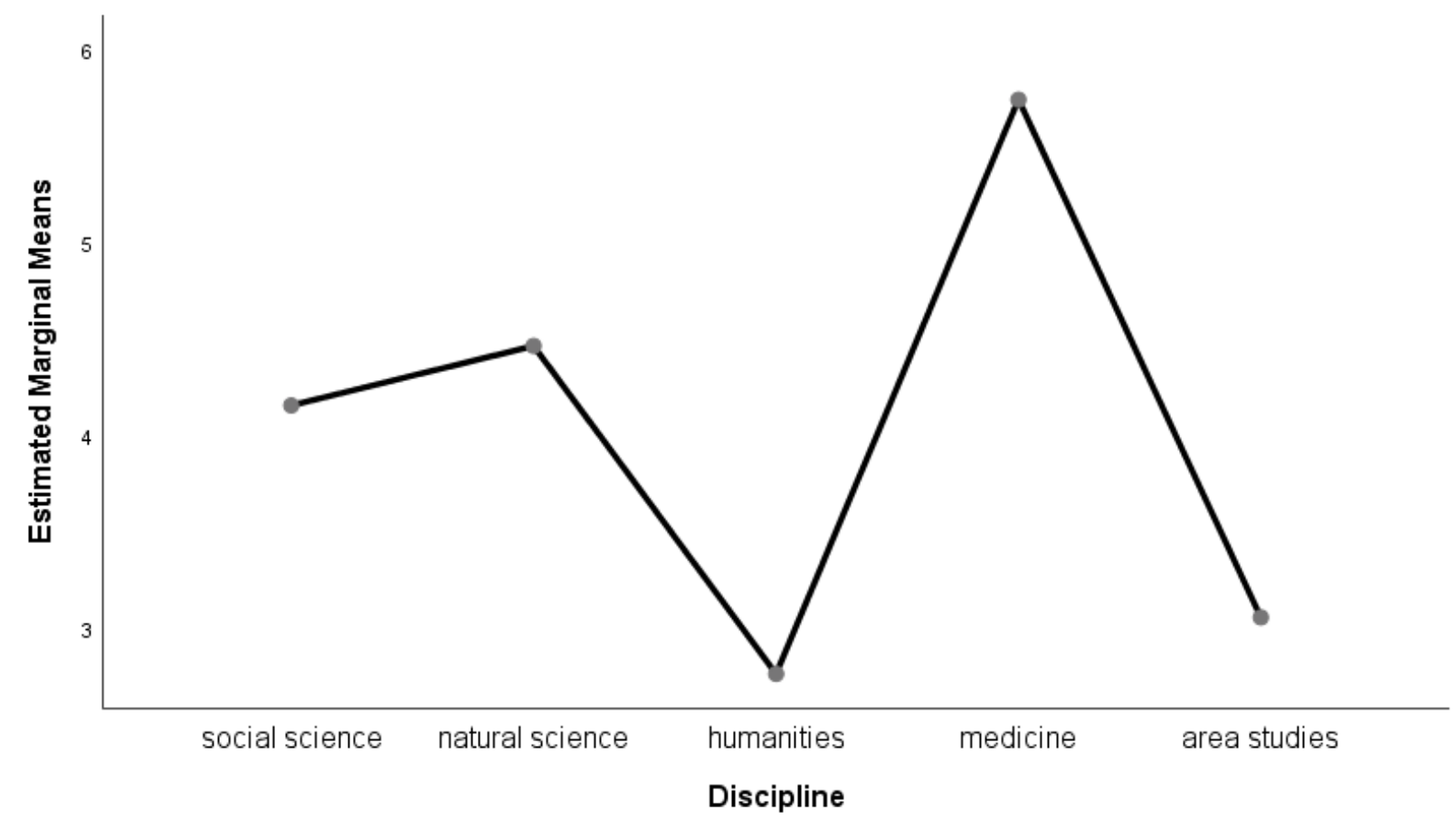

The main effects of discipline $\left(F(4,8964)=84.138, p<0.001\right.$, partial $\eta^{2}=0.036$ (Figure 5)) and experience $\left(F(2,8964)=14.569, p<0.001\right.$, partial $\eta^{2}=0.003$ (Figure 6)) were also significant for faculty views on replacing libraries' print collections with electronic formats. However, the interaction was not significant. It would appear that medicine is most in favor of the idea $(M=7.23)$ closely followed by natural science $(M=6.84)$ and social science $(M=6.67)$, while humanities $(M=5.28)$ and area studies $(M=5.44)$ are barely above the mean. Looking at the experience levels, all groups fall above the mean indicating some overall level of comfort with the idea. The least experienced group (0 to 10 years) was most in favor ( $M=6.66)$ followed by faculty with 11 to 20 years of experience $(M=6.46)$ and finally those with over 21 years of experience $(M=5.80)$. The effect size indicates that disciplinary differences exert more influence than the experience.

Figure 5 
I would be happy to see hard copy collections replaced by electronic collections

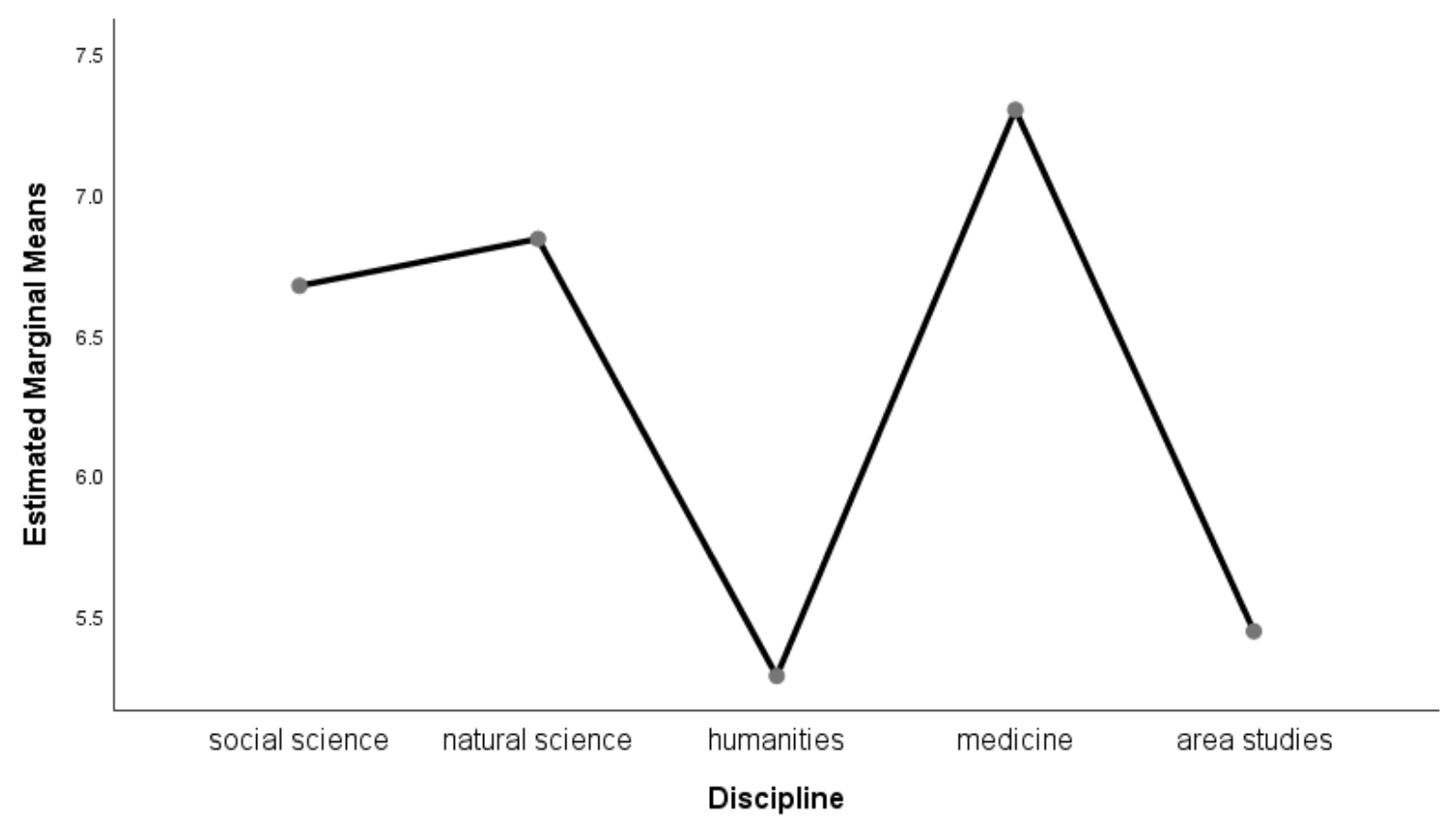

Figure 6

I would be happy to see hard copy collections replaced by electronic collections

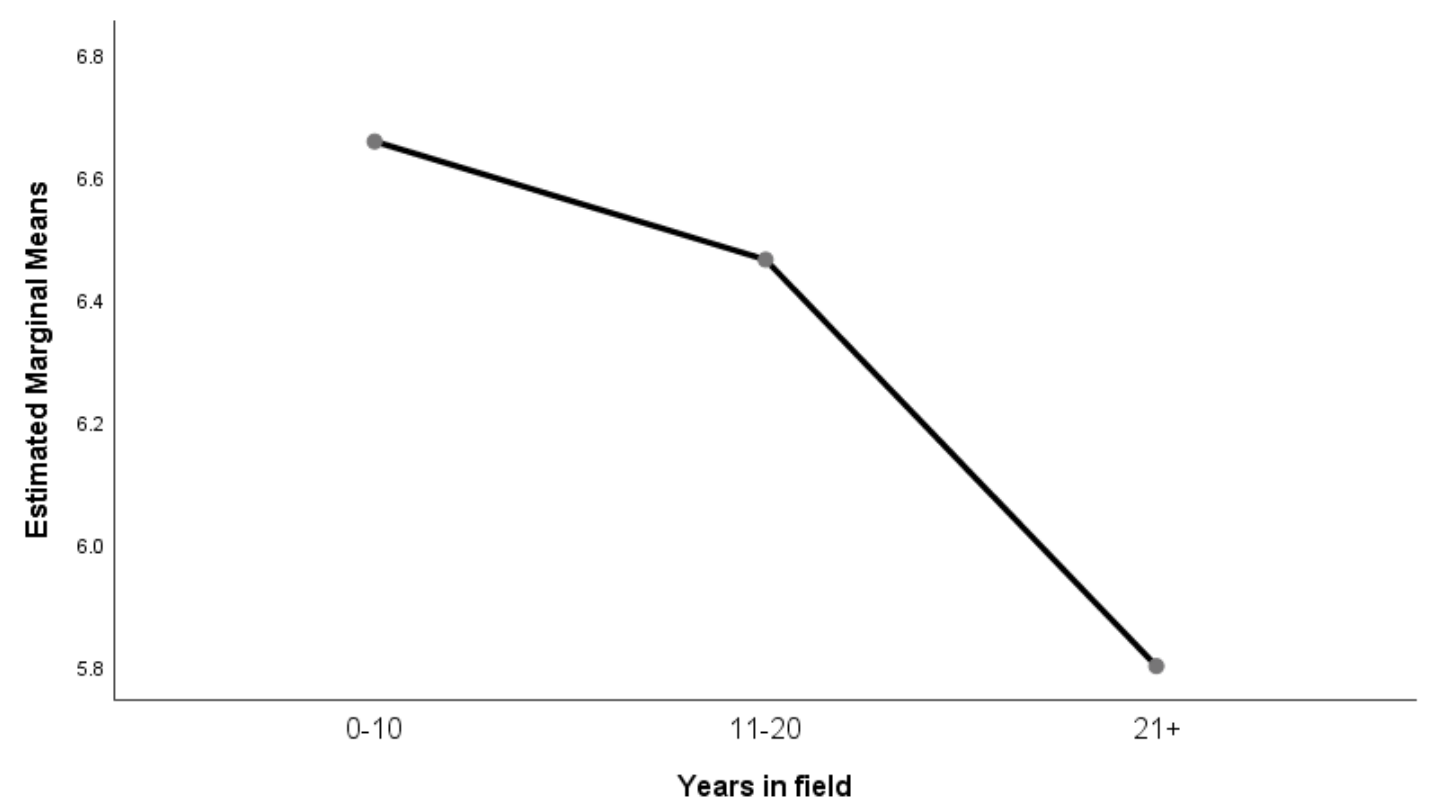


Similarly, regarding replacing print with electronic journals, both main effects of discipline $(F(4$, $8960)=99.410, p<0.001$, partial $\eta^{2}=0.042($ Figure 7$\left.)\right)$ and experience $(F(2,8960)=9.367, p<0.001$, partial $\eta^{2}=0.002$ (Figure 8)) were significant, while the interaction was not. Overall, both groupings are significantly above the mean indicating greater level of comfort with the idea of electronic journal collections. At the lower end, humanities $(M=7.11)$ and area studies $(M=7.27)$ fall more than 2 points above the mean. Medicine leads the trend $(M=8.59)$ followed by natural sciences $(M=8.58)$ and social science ( $M=8.27)$. Looking at experience levels, the mean difference between the least experienced group $(M=8.27)$ and the most experienced group $(M=7.64)$ was only 0.625 . In conjunction with relatively small effect size, discipline again appears to have more effect on journal format preference.

Figure 7

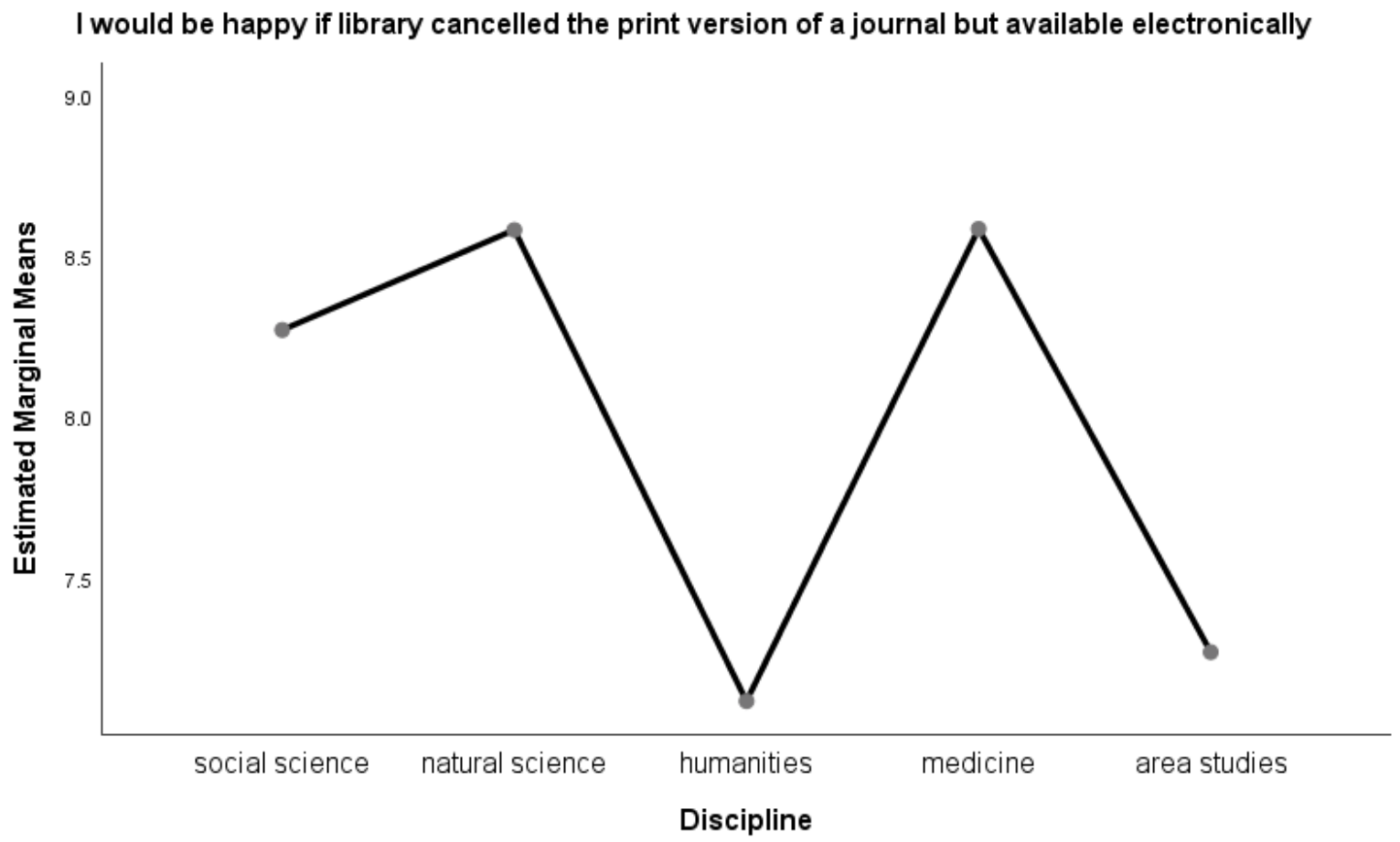


Insert Figure 8

Finally, for comfort level with publishing journals in e format only, both main effects of discipline $\left(F(4,8969)=103.200, p<0.001\right.$, partial $\eta^{2}=0.044$ (Figure 9)) and experience $(F(2,8969)=10.561, p<$ 0.001 , partial $\eta^{2}=0.002$ (Figure 10)) were significant. Although all disciplines fall above the mean indicating a generally favorable view of publishers switching to electronic only journal publishing, humanists are least likely to agree $(M=6.04)$ followed by area studies $(M=6.314)$. Natural science $(M=7.90)$, medicine $(M=7.54)$ and social science $(M=7.28)$ represent a second, closely aligned group, much more comfortable with the idea. While the effect of experience was small and the mean difference between the least and most experienced group only 0.73 , as seen in figure 10 , the trend is clear and level of experience plays a role in format preference. Interaction effect was not significant.

Figure 9

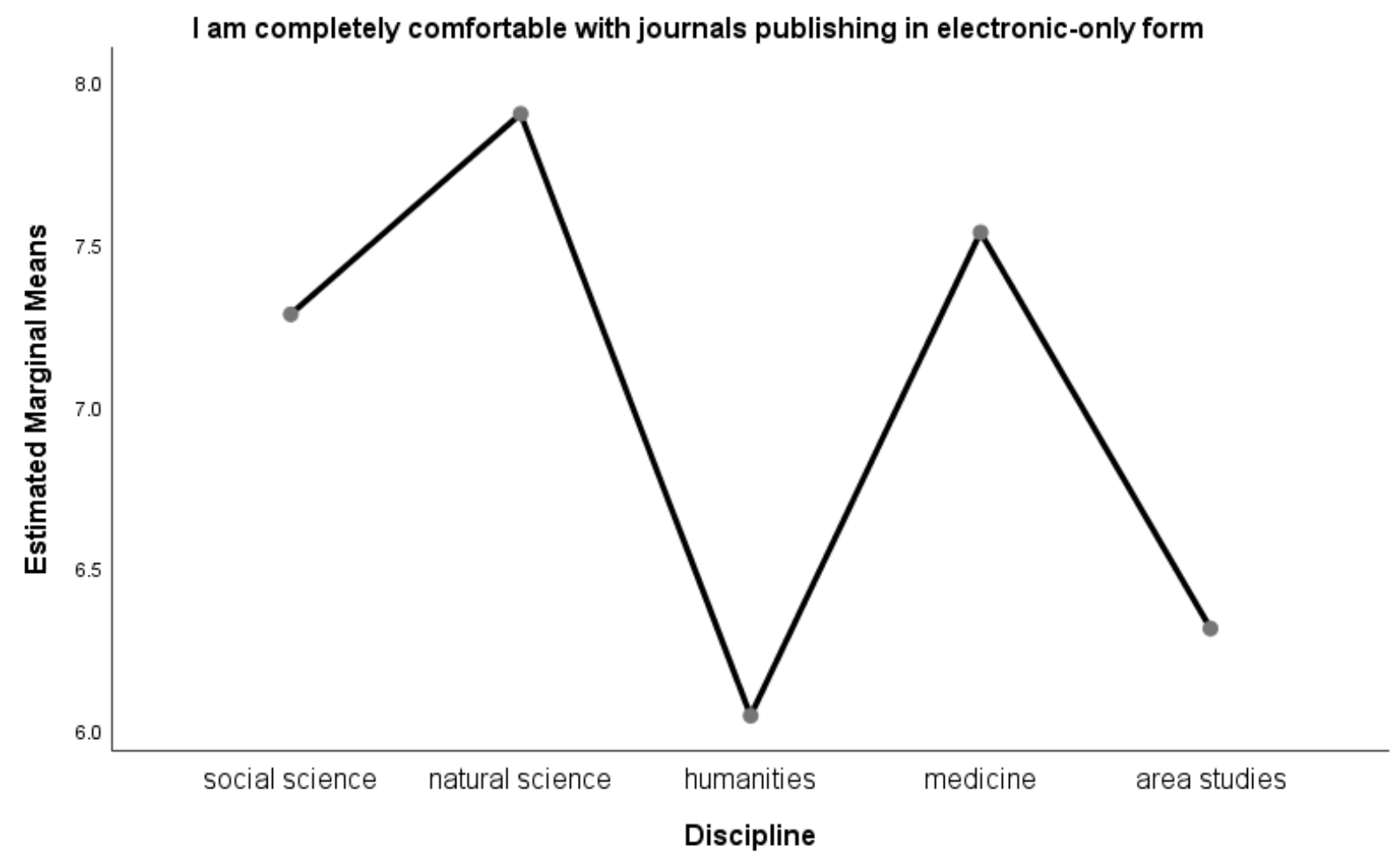

Figure 10 


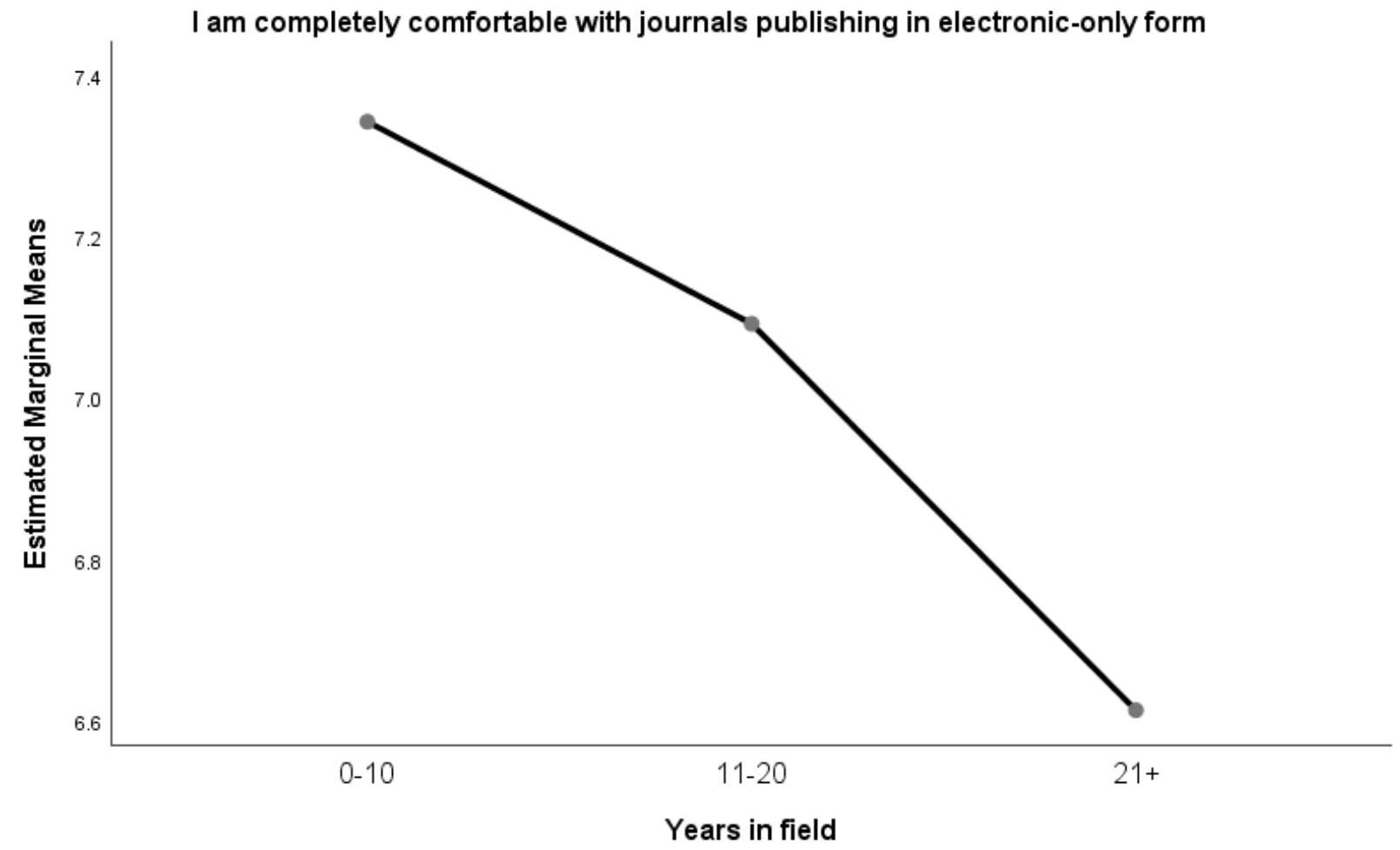

\section{DISCUSSION AND CONCLUSION}

The purpose of this study was to examine the potential effects of academic discipline, years of experience in the field and faculty format preferences for books and journals. Overall, surveyed faculty had favorable views of electronic journal formats, both in terms of publishing preferences and library holdings. Most also agreed print books were important in their research and teaching, and were less inclined to believe e books would be prevalent in the next 5 years. Several important trends emerge. While both experience and discipline were statistically significant for all variables in the study, the effect size of discipline was much larger and, therefore, played a much more prominent role in format preference. Although current research lacks sufficient studies in the area of the effects of experience, findings regarding effects of disciplines on format preference are largely supported (e.g., Bar-Ilan \& Fink, 2005; Martins, Machado, Fernandes \& Ribeiro, 2015).

Print monographs seem to be important to participants across discipline and experience groups. Not surprisingly, disciplines traditionally reliant on monographs such as humanities and area studies showed much stronger preference for print books than sciences and medicine, which is also supported 
by previous research (e.g., Talja \& Maula, 2003). Interestingly, unlike all other disciplines, medicine and natural science faculty seemed to value print books slightly more at the beginning and toward the end of their career. While the literature seems to be silent on this point - and there could be many reasons for this trend - incoming medical professionals and scientists might simply be relying on reference monographs more toward the beginning their career.

Opinions regarding e-book relevance in 5 years are in many ways the inverse of print collection importance. Humanists and area studies faculty are largely not convinced. This was certainly true of artists who were concerned with the quality of art reproductions (Robinson, 2010). Similarly, both social and natural scientists are also, at best, ambivalent on the topic. Some of this sentiment could, no doubt, be attributed to their overall lesser interest in monographs regardless of format. Tenopir et al., (2015), in their recent study of interdisciplinary differences among university faculty, found social scientists and natural scientists, indeed, tend to favor journal articles in their research. Medicine follows the same pattern showing strong preference for journal articles over monographs. However, if preference for journal articles was the only difference, medicine would follow the same pattern in the current study. Instead, medical faculty held a much more favorable opinion on the future of e-books even though they follow the same pattern as natural science when it came to print book preference.

Perhaps the most striking result in the study is the overall favorable attitude toward doing away with libraries' print collections in their entirety. Interdisciplinary and experiential differences notwithstanding, most participants were at least somewhat open to the idea. Even humanities scholars, who expressed reservations over e-book prevalence in the near future and strong support for print monographs in their research and teaching, were slightly in support of electronic over print collections. Dream of instantly available information with none of the current disadvantages of e-formats seems to be very much alive.

Empirical studies regarding format preferences spanning multiple institutions with enough participants to support meaningful analysis tend to be rare. Future studies are needed to further explore trends in scholar's engagement with library collections. For instance, more detailed examination of sub disciplines would provide a more comprehensive view of possible differences in opinion and highlight additional trends. Similarly, cross institutional studies of usage trends would help complement the opinion based trends discussed in the current study. 
Finally, format-based usage trends are highly sensitive to technology adoption cycles. Studies exploring these links, as well as updates to the current study with new datasets in the ITHAKA series, could be highly illuminating for future collection development librarians.

\section{REFERENCES}

Bar-llan, J., \& Fink, N. (2005). Preference for electronic format of scientific journals: A case study of the Science Library users at the Hebrew University. Library \& Information Science Research, 27(3), 363-376. https://doi-org.pallas2.tcl.sc.edu/10.1016/j.lisr.2005.04.011

Becker, L. A., \& Coolidge, F. L. (1991). On the proper interpretation of residualized interaction means in an analysis of variance: A reply to Rosnow and Rosenthal. Psychological Reports, 68, 483-490.

https://doi.org/10.2466/pr0.1991.68.2.483

Biglan, A. (1973). The characteristics of subject matter in different academic areas. Journal of Applied Psychology. 57(3):195-203.

Burton, S. S. (2015). The academic e-book landscape: technological problems. CILIP Update, 40-41. https://login.pallas2.tcl.sc.edu/login?url=http://search.ebscohost.com/login.aspx?direct=true\&db=Ilf\&A $\mathrm{N}=102928285 \&$ site $=$ ehost-live

Carrico, S.B., Cataldo, T.T., Botero, C., \& Shelton, T. (2015). What cost and usage data reveals about ebook acquisitions: Ramifications for collection development. ALCTS, 59(3).

https://journals.ala.org/Irts/article/view/5752/7199 
Costello, L. (2017). Comparison of e-book acquisitions strategies across disciplines finds differences in cost and usage. Evidence Based Library \& Information Practice, 12(1), 109-111. https://doiorg.pallas2.tcl.sc.edu/10.18438/B8ZP70

Dermody, K., \& Majekodunmi, N. (2011). Online databases and the research experience for university students with print disabilities. Library Hi Tech, 29(1), 149-160. https://doi-

org.pallas2.tcl.sc.edu/10.1108/0737883111111697

Ellis, D., \& Oldman, H. (2005). The English literature researcher in the age of the Internet. Journal of Information Science, 31(1), 29-36. https://doi-org.pallas2.tcl.sc.edu/10.1177/0165551505049256

Foote, J. \& Rupp-Serrano, K. (2010). Exploring E-book usage among faculty and graduate students in the geosciences: results of a small survey and focus group approach. Science \& Technology Libraries, 29(3), 216-234. DOI:10.1080/0194262X.2010.497716

Horava, T. (2008). Mission possible: E-books and the humanities. Acquisitions Librarian, 19(3/4), 325352. https://doi.org/10.1080/08963570802026393

Kichuk, D. (2015). Loose, falling characters and sentences: The persistence of the OCR problem in digital repository E-Books. Portal: Libraries \& the Academy, 15(1), 59-91.

https://doi.org/10.1353/pla.2015.0005

Knowlton, S. (2016). A two-step model for assessing relative interest in e-books compared to print. College \& Research Libraries, 77(1), 20-33. https://doi-org.pallas2.tcl.sc.edu/10.5860/crl.77.1.20

Levine-Clark, M., Paulson, K., \& Moeller, P. (2015). 10,000 Libraries, 4 Years: A Large-Scale Study of EBook Usage and How You Can Use the Data to Move Forward. Serials Librarian, 68(1-4), 262-268. https://doi.org/10.1080/0361526X.2015.1017709

Lewellen, R., Bischof, S., \& Plum, T. (2016). EBL ebook use compared to the use of equivalent print books and other eresources. Performance Measurement \& Metrics, 17(2), 150-164. https://doi-

org.pallas2.tcl.sc.edu/10.1108/PMM-04-2016-0013

Martins, F., Machado, D., Fernandes, A., \& Ribeiro, F. (2015). Electronic Journals: Their Use By Teachers/Researchers Of Engineering And Social Sciences. AIP Conference Proceedings, 1644(1), 17-23. https://doi-org.pallas2.tcl.sc.edu/10.1063/1.4907812

McCann, S., \& Ravas, T. (2010). Impact of Image Quality in Online Art History Journals: A User Study. Art Documentation: Bulletin of the Art Libraries Society of North America, 29(1), 41-48. Retrieved from http://search.ebscohost.com.pallas2.tcl.sc.edu/login.aspx?direct=true\&db=aft\&AN=502989127\&site=ed $\underline{\text { s-live }}$

Mune, C., \& Agee, A. (2016). Are e-books for everyone? An evaluation of academic e-book platforms' accessibility features. Journal of Electronic Resources Librarianship, 28(3), 172-182. https://doiorg.pallas2.tcl.sc.edu/10.1080/1941126X.2016.1200927

Murata, C., \& Pan, D. (2018, July 01). Collections budget allocation practices survey and results. Retrieved March 13, 2019, from https://digital.lib.washington.edu/researchworks/handle/1773/43180 
Nicholas, D., Williams, P., Rowlands, I., \& Jamali, H. R. (2010). Researchers' e-journal use and information seeking behaviour. Journal of Information Science, 36(4), 494-516. https://doiorg.pallas2.tcl.sc.edu/10.1177/0165551510371883

Ritchie, A., \& Skoglund, H. (2015). Ebooks at Barwon Health Library: a case study. Australian Library Journal, 64(3), 180-193. https://doi-org.pallas2.tcl.sc.edu/10.1080/00049670.2015.1048042

Robinson, A. (2010). University of Kansas Print and Electronic Journal Comparison Study. Art Documentation: Bulletin of the Art Libraries Society of North America, 29(1), 37-40. https://doiorg.pallas2.tcl.sc.edu/10.1086/adx.29.1.27949537

Rowlands, I., Nicholas, D., \& Jubb, M. (2009). Does e-journal investment lead to greater academic productivity? Library \& Information Update, 45-47. Retrieved from https://login.pallas2.tcl.sc.edu/login?url=http://search.ebscohost.com/login.aspx?direct=true\&db=lih\&A $\underline{\mathrm{N}=44446112 \& \text { site }=\text { ehost-live }}$

Salisbury, L. (2004). Evidence-based Services at the University of Arkansas Libraries: Results of a Faculty Survey to Assess the Usefulness of Electronic Resources. Quarterly Bulletin of the International Association of Agricultural Information Specialists, 49(1/2), 36-40. Retrieved from http://search.ebscohost.com.pallas2.tcl.sc.edu/login.aspx?direct=true \&db=If\&AN=502916346\&site=eh ost-live

Salisbury, L. (2005). Usability of E-journals and Preference for the Virtual Periodicals Room: a Survey of Mathematics Faculty and Graduate Students . Electronic Journal of Academic \& Special Librarianship, 4(2/3), 1. Retrieved from http://search.ebscohost.com.pallas2.tcl.sc.edu/login.aspx?direct=true \&db=|lf\&AN=502912330\&site=eh ost-live

Scott, A., \& Best, R. (2016). Using Choice to Measure the Availability and Use of E-Books. Southeastern Librarian, 64(3), 12-21. Retrieved from

http://search.ebscohost.com.pallas2.tcl.sc.edu/login.aspx?direct=true\&db=If\&AN=127118903\&site=eh ost-live

Simon, C. (2011). Just the facts: An examination of E-Book usage by business students and faculty. Reference Librarian, 52(3), 263-273. https://doi.org/10.1080/02763877.2011.556561

Smith, S. L., Rodriguez, A., Miller, E., DeWitt, \& Xu, L. (2019). The relationship between the technology acceptance model and preference for e-books at a large research university. Library Hi Tech News, 36(3), 13-15. https://doi-org.pallas2.tcl.sc.edu/10.1108/LHTN-11-2018-0069

Soaring e-journal use, but not in libraries. (2011). CILIP Update, 10(3), 13. Retrieved from https://login.pallas2.tcl.sc.edu/login?url=http://search.ebscohost.com/login.aspx?direct=true\&db=lih\&A $\mathrm{N}=59763744 \&$ site=ehost-live

Speier, C., \& Palmer, J. (1999). Faculty Perceptions of Electronic Journals as Scholarly Communication: A Question of Prestige and Legitimacy. Journal of the American Society for Information Science, 50(6), 537543. https://doi.org/10.1002/(SICI)1097-4571(1999)50:6<537::AID-ASI9>3.0.CO;2-6 
Talja, S., \& Maula, H. (2003). Reasons for the use and non-use of electronic journals and databases. Journal of Documentation, 59(6), 673-691.

Tenopir, C., King, D. W., Christian, L., \& Volentine, R. (2015). Scholarly article seeking, reading, and use: a continuing evolution from print to electronic in the sciences and social sciences. Learned Publishing, 28(2), 93-105. https://doi.org/10.1087/20150203

Tucker, J. (2012). Ebook collection analysis: subject and publisher trends. Collection Building, 31(2), 4047. https://doi.org/10.1108/01604951211229836

Warner, R. M. (2012). Applied statistics: From bivariate through multivariate techniques (2nd ed.). Los Angeles, CA: Sage.

Weijing Yuan, Van Ballegooie, M., \& Robertson, J. L. (2018). Ebooks Versus Print Books: Format Preferences in an Academic Library. Collection Management, 43(1), 28-48. https://doi-

org.pallas2.tcl.sc.edu/10.1080/01462679.2017.1365264

Whitmire, E. (2002). Disciplinary differences and undergraduates' information-seeking behavior. Journal of the American Society for Information Science and Technology, 53(8), 631-638.

Wolff, C., Schonfeld, R. C., \& Rod, A. B. (2016). Ithaka S+ R US library survey 2015. Ithaka S+ R.

Yuan, W., Van Ballegooie, M., \& Robertson, J. (2018). Ebooks Versus Print Books: Format Preferences in an Academic Library. Collection Management, 43(1), 28-48.

https://doi.org/10.1080/01462679.2017.1365264

Tao Zhang, Xi Niu, \& Promann, M. (2017). Assessing the user experience of e-books in academic libraries. College \& Research Libraries, 78(5), 578-601. https://doi-org.pallas2.tcl.sc.edu/10.5860/crl.78.5.578 